\title{
PENGGUNAAN STRATEGI MIND MAPPING BERBASIS MULTIMEDIA UNTUK MENINGKATKAN HASIL BELAJAR IPS PADA SISWA KELAS V SDN I WONOREJO DEMAK
}

\section{Lilis Triana}

SDN I Wonorejo Karanganyar Demak

Jawa Tengah, Indonesia

\section{Info Artikel}

Sejarah Artikel:

Diterima September 2016

Disetujui November 2016

Dipublikasikan Desember

2016

\section{Keywords:}

Mind Mapping,

Multimedia, Hasil Belajar IPS

\begin{abstract}
The purposes that want to achoeved in this research are to know the progress of study at $5^{\text {th }}$ grade in society subject that used Mind Mapping base on multimedia strategy. This research applying class room action research (PTK) that consisted of two cycles. Research subject are teacher and $5^{\text {th }}$ grade students of SDN I Wonorejo Demak that amounted of 29 students. Research result data obtained throgh observation and test. analysis technique that applied namely descriptive qualitative and quantitative data abalysis technique. Research results show that teacher activity on first cycle as big as $60 \%$, while on second ones teacher activity score increase to $80 \%$. Student activity on first cycle as big as $60 \%$, while on second ones teacher activity score increase to $97 \%$. Meanwhile student learning result on first cycle show completeness percentage reach to 59\%, and on second cycles improve with classical completeness percentage reach to $86,25 \%$.
\end{abstract}

\begin{abstract}
Abstrak
Tujuan yang ingin dicapai dalam penelitian ini yaitu untuk mengetahui peningkatan hasil belajar siswa kelas V pada mata pelajaran IPS menggunakan strategi pembelajaran Mind Mapping berbasis multimedia. Penelitian ini menggunakan rancangan penelitian tindakan kelas (PTK) yang terdiri atas dua siklus. Subjek penelitian ini adalah guru dan siswa kelas V SDN I Wonorejo Demak yang berjumlah 29 siswa. Data hasil penelitian ini diperoleh melalui aktivitas guru, aktivitas siswa dan tes. Teknik analisis data yang digunakan adalah teknik analisis data deskriptif kualitatif dan kuantitatif. Hasil penelitian menunjukkan bahwa aktivitas guru pada siklus I sebesar 60\%, sedangkan pada siklus II skor aktivitas guru meningkat menjadi 80\%. Aktivitas siswa pada siklus I sebesar 60\%, sedangkan pada siklus II mengalami peningkatan menjadi $97 \%$. Sementara itu hasil belajar siswa pada siklus I menunjukkan persentase ketuntasan klasikal mencapai 59\% dan pada siklus II persentase ketuntasan klasikan mencapai $86,25 \%$.
\end{abstract}

(C) 2016 Universitas Muria Kudus

Alamat korespondensi:

p-ISSN 2087-9385

Program Studi Pendidikan Guru Sekolah Dasar

e-ISSN 2528-696X

Fakultas Keguruan dan Ilmu Pendidikan Universitas Muria Kudus

Kampus UMK Gondangmanis, Bae Kudus Gd. L. It I PO. BOX 53

Kudus

Tlp (0291) 438229 ex.147 Fax. (0291) 437198

E-mail: mybubble_ia@yahoo.co.id 


\section{PENDAHULUAN}

Undang-Undang No. 20 Tahun 2003 tentang Sistem Pendidikan Nasional Bab I Pasal 1 menyebutkan bahwa pendidikan adalah usaha sadar dan terencana untuk mewujudkan suasana belajar dan proses pembelajaran agar peserta didik secara aktif mengembangkan potensi dirinya untuk memiliki kekuatan spiritual keagamaan, pengendalian diri, kepribadian, kecerdasan, akhlak mulia, serta keterampilan yang diperlukan dirinya, masyarakat, bangsa dan negara sedangkan pendidikan nasional adalah pendidikan yang berdasarkan Pancasila dan Undang- Undang Dasar Negara Republik Indonesia Tahun 1945 yang berakar pada nilainilai agama, kebudayaan nasional Indonesia dan tanggap terhadap tuntutan perubahan zaman (Depdiknas, 2006:56). Selain itu di dalam UU No. 20 Tahun 2003 Pasal 3 dijelaskan pula tujuan pendidikan adalah mengembangkan potensi peserta didik agar menjadi manusia yang beriman dan bertaqwa kepada Tuhan Yang Maha Esa, berakhlak mulia, sehat,berilmu, cakap, kreatif, mandiri, dan menjadi warga negara yang demokratis serta bertanggungjawab (Wahyudin, 2008: 2.12). IPS sebagai salah satu program pendidikan tidak hanya menyajikan tentang konsep-konsep pengetahuan semata, namun IPS harus mampu membina peserta didik menjadi warga negara dan warga masyarakat.

Mata pelajaran IPS mengkaji seperangkat peristiwa, fakta, konsep, dan generalisasi yang berkaitan dengan isu sosial. Pada jenjang SD/MI mata pelajaran IPS memuat materi Geografi, Sejarah, Sosiologi, dan Ekonomi. Melalui mata pelajaran IPS, peserta didik diarahkan untuk dapat menjadi warga negara Indonesia yang demokratis, dan bertanggung jawab, serta warga dunia yang cinta damai.

Mata pelajaran IPS bertujuan agar peserta didik memiliki kemampuan sebagai berikut: 1) mengenal konsep-konsep yang berkaitan dengan kehidupan masyarakat dan lingkungannya; 2) memiliki kemampuan dasar untuk berpikir logis dan kritis, rasa ingin tahu, inkuiri, memecahkan masalah, dan keterampilan dalam kehidupan sosial; 3) memiliki komitmen dan kesadaran terhadap nilai nilai sosial dan kemanusiaan; 4) memiliki kemampuan berkomunikasi, bekerjasama dan berkompetisi dalam masyarakat yang majemuk, ditingkat lokal, nasional dan global. (Depdiknas, 2007:575).
Hasil penelitian yang dilakukan oleh Depdiknas Balitbang Pusat Kurikulum (2007:6) yang berisi mengenai kajian kebijakan kurikulum mata pelajaran IPS menunjukan bahwa masih banyak permasalahanpermasalahan pelaksanaan Standar Isi, salah satunya ialah strategi atau pendekatan pembelajaran yang salah pemahaman yaitu menganggap bahwa pelajaran Ilmu Pengetahuan Sosial sebagai pelajaran yang cenderung hafalan. Pemahaman seperti ini berakibat pada pembelajaran yang lebih menekankan verbalisme atau secara lisan. Guru dalam menerapkan metode pembelajaran lebih menekankan pada aktivitas guru, bukan aktivitas siswa. Pembelajaran yang dilakukan kurang variatif, misalnya guru lebih banyak menggunakan metode ceramah atau bahkan menyuruh siswanya untuk mencatat.

Hasil analisis peneliti terhadap nilai evaluasi hasil belajar siswa pada mata pelajaran Ilmu Pengetahuan Sosial kelas V SDN I Wonorejo pada semester 1 menunjukkan belum tercapainya Kriteria Ketuntasan Minimal (KKM) yang ditetapkan yaitu 65. Sebagian siswa dinilai tidak dapat memahami pelajaran yang disampaikan oleh guru. Hal tersebut terlihat dari data evaluasi hasil belajar, dimana sebanyak 14 siswa dari 29 siswa mendapat nilai dibawah KKM. Dengan demikian menunjukan sekitar 50\% siswa masih belum dapat mencapai nilai KKM. Hal ini yang mengindikasikan bahwa sebagian besar siswa kelas IV SDN Purwoyoso 06 belum dapat memahami dan menguasai materi pembelajaran Ilmu Pengetahuan Sosial (IPS).

Berdasarkan pengalaman yang secara langsung dirasakan oleh peneliti selama pembelajaran di kelas diperoleh simpulan bahwa masalah yang timbul dalam pembelajaran Ilmu Pengetahuan Sosial (IPS) di kelas V SDN I Wonorejo dipengaruhi oleh beberapa faktor, antara lain adalah faktor mengajar guru yang belum mengembangkan pembelajaran bermakna dan mandiri yang inovatif di kelas. Guru belum menggunakan strategi, metode, maupun pendekatan pembelajaran yang tepat, siswa lebih ditekankan pada kebiasaan mencatat penjelasan guru dan belum diarahkan belajar mandiri untuk menemukan sendiri informasi yang berhubungan dengan materi, sehingga siswa cenderung cepat merasa bosan dalam pembelajaran IPS. Selain itu penggunaan media 
pembelajaran yang menarik sebagai pendukung pembelajaran juga belum optimal ditandai dengan masih terbatasnya guru dalam menggunakan media pembelajaran yang hanya memanfaatkan media pandang seperti gambargambar sehingga belum mampu menarik perhatian siswa dalam mengikuti pembelajaran IPS.

Berdasarkan permasalahan yang dijumpai pada proses pembelajaran tersebut, untuk memecahkan permasalahan pembelajaran Ilmu Pengetahuan Sosial (IPS) di SDN I Wonorejo, maka peneliti menetapkan pemecahan masalah dengan menggunakan strategi belajar peta konsep (mind mapping) berbasis multimedia.

Mind mapping adalah cara termudah untuk menempatkan informasi kedalam otak dan mengambil informasi ke luar otak dari otak. Dengan mind mapping, daftar informasi yang panjang bisa dialihkan menjadi diagram warnawarni, sangat teratur, dan mudah diingat yang bekerja selaras dengan cara kerja alami otak dalam melakukan berbagai hal (Buzan, 2007: 47). Penggunaan strategi pembelajaran mind mapping melibatkan kedua belahan otak, sehingga melibatkan sistem limbik (melibatkan emosi positif), yaitu dapat membuat siswa senang saat belajar karena melibatkan otak kanan.

Keunggulan Mind Map menurut Yovan (dalam Astutiamin (2009)) antara lain: 1) tema utama terdefenisi secara sangat jelas karena dinyatakan di tengah, 2) level keutamaan informasi teridentifikasi secara lebih baik. Hubungan masing-masing informasi dapat secara mudah dikenali. Lebih mudah dipahami dan diingat. Informasi baru setelahnya dapat segera digabungkan tanpa merusak keseluruhan struktur Mind Map, sehingga mempermudah proses pengingatan.

Tujuan penelitian ini adalah untuk 1) meningkatkan keterampilan guru dalam pembelajaran IPS melalui penerapan strategi mind mapping berbasis multimedia di kelas $\mathrm{V}$ SDN I Wonorejo, 2) meningkatkan aktivitas siswa dalam pembelajaran IPS melalui penerapan strategi mind mapping berbasis multimedia di kelas V SDN I Wonorejo, dan 3) meningkatkan hasilbelajar siswa dalam pembelajaran IPS melalui penerapan strategi mind mapping berbasis multimedia di kelas $\mathrm{V}$ SDN I Wonorejo.

\section{METODE}

Rancangan penelitian yang digunakan adalah Penelitian Tindakan Kelas (PTK). Menurut Kunandar (2008:46-47), penelitian tindakan kelas merupakan penelitian kualitatif meskipun data yang dikumpulkan bisa saja bersifat kuantitatif. Penelitian ini menggunakan metode diskriptif kuantitatif yang digunakan untuk mengolah persentase aktifitas guru dan aktivitas siswa, serta hasil belajar siswa berupa menggambar dekoratif.

Arikunto (2011:3) menyatakan bahwa PTK merupakan pencermatan terhadap kegiatan belajar berupa sebuah tindakan yang sengaja dimunculkan dan terjadi dalam sebuah kelas secara bersama. Tujuan utamanya adalah untuk memecahkan permasalahan nyata yang terjadi di kelas dan meningkatkan kegiatan nyata guru dalam kegiatan pengembangan profesinya.

Pada penelitian tentang pembelajaran Ilmu Pengetahuan Sosial (IPS), strategi pembelajaran Mind mapping digunakan untuk memperbaiki mutu proses belajar mengajar yang selama ini cenderung bersifat verbal sehingga ada suatu variasi pembelajaran yang diharapkan dapat meningkatkan hasil belajar siswa.

Prosedur pelaksanaan tindakan kelas ini dimulai dengan siklus I. Bila pada siklus I masih banyak yang tidak memenuhi KKM maka akan dilanjutkan pada siklus-siklus selanjutnya.

Subjek penelitian ini adalah seluruh siswa dan kelas V SDN I Wonorejo dengan jumlah 29 siswa. Pemilihan siswa kelas V sebagai subyek penelitian berdasarkan atas tahap perkembangan anak siswa kelas $\mathrm{V}$ yang dianggap telah mampu melakukan pemahaman dan mampu bernalar melalui penggunaan hipotesis dan implementasi konsep, serta sudah mampu untuk berfikir secara abstrak.

Dalam penelitian ini peneliti melakukan pengumpulan data dengan menggunakan teknik tes dan non tes. Menurut Poerwanti (2008:1.5) yang dimaksud dengan tes adalah seperangkat tugas yang harus dikerjakan oleh peserta didik untuk mengukur tingkat pemahaman dan penguasaan terhadap cakupan materi yang dipersyaratkan dan sesuai dengan tujuan tertentu Teknik tes dalam penilitian ini digunakan untuk mengukur kemampuan dasar dan pencapaian atau prestasi belajar. Tes diberikan kepada siswa secara individu untuk mengetahui kemampuan kognitif siswa. Tes juga digunakan untuk mengukur atau memberi 
angka terhadap proses pembelajaran ataupun pekerjaan siswa sebagai hasil belajar yang merupakan cerminan tingkat penguasaan terhadap materi yang diajarkan. Tes ini dilaksanakan pada pembelajaran siklus I dan siklus II.

Teknik non tes dilakukan dengan cara observasi menggunakan alat pengumpulan data berupa lembar observasi, catatan lapangan, dan dokumentasi.

\section{HASIL PENELITIAN DAN PEMBAHASAN}

Penelitian tindakan kelas ini dilaksanakan di SDN I Wonorejo dengan subjek penelitian sebanyak 29 siswa. Penelitian Tindakan Kelas ini dilaksanakan dengan menerapkan strategi belajar mind mapping berbasis multimedia. Pada penelitian tindakan kelas ini peneliti melakukan penelitian pada proses pembelajaran sebanyak 2 siklus dengan masing-masing siklus 1 pertemuan. Tiap pertemuan diadakan evaluasi untuk mengukur ketercapaian indikator pembelajaran yang telah ditetapkan.

Siklus I

Pelaksanaan tindakan siklus I dilaksanakan pada tanggal 10 Mei 2016. Pelaksanaan tindakan dilaksanakan dengan menerapkan strategi belajar mind mapping berbasis multimedia pada pembelajaran IPS.

Berdasarkan pelaksanaan tindakan yang dilakukan selama kegiatan pembelajaran IPS melalui penerapan strategi mind mapping berbasis multimedia pada siklus I, diperoleh hasil sebagai berikut.

a) Hasil observasi keterampilan guru

Kegiatan observasi dilakukan guna mengamati keterampilan guru dalam pembelajaran IPS melalui strategi mind mapping berbasis multimedia.

Tabel 1. Hasil observasi keterampilan guru siklus I

\begin{tabular}{ll}
\hline Indikator & Perolehan Skor \\
\hline 1. Keterampilan membuka pelajaran & 2 \\
\hline 2. Keterampilan memberikan pertanyaan & 2 \\
\hline 3. Keterampilan menjelaskan materi & 3 \\
\hline 4. Keterampilan menggunakan multimedia & 3 \\
\hline 5. Keterampilan pembelajaran perseorangan & 2 \\
\hline $\begin{array}{l}\text { 6. Keterampilan membimbing diskusi kelompok } \\
\quad \text { kecil dengan menerapkan strategi mind mapping }\end{array}$ & 3 \\
\hline 7. Keteampilan mengelola kelas & 2 \\
\hline 8. Keterampilan mengadakan variasi & 3 \\
\hline 9. Keterampilan memberikan penguatan & 2 \\
\hline 10.Keterampilan menutup pelajaran & 2 \\
\hline Total Skor & 24 \\
\hline Persentase & $60 \%$ \\
\hline Kategori & Cukup \\
\hline
\end{tabular}

b) Hasil observasi aktivitas siswa

Hasil observasi siswa pada pelaksanaan tindakan siklus I pada pembelajaran IPS melalui penerapan strategi mind mapping berbasis multimedia di kelas $\mathrm{V}$ SDN Wonorejo I, dapat dilihat pada tabel berikut.

Tabel 2. Hasil Observasi Aktivitas Siswa Siklus I

\begin{tabular}{|c|c|c|c|c|c|c|c|c|c|}
\hline \multirow[t]{2}{*}{ No. } & \multirow{2}{*}{ Aspek yang dinilai } & \multicolumn{4}{|c|}{$\begin{array}{l}\text { Jumlah siswa yang } \\
\text { mendapatkan skor }\end{array}$} & \multirow{2}{*}{$\begin{array}{l}\text { Skor } \\
\text { Mak. }\end{array}$} & \multirow{2}{*}{$\begin{array}{l}\text { Jumlah } \\
\text { Skor }\end{array}$} & \multirow{2}{*}{$\begin{array}{l}\text { Rata- } \\
\text { rata }\end{array}$} & \multirow[t]{2}{*}{$\%$} \\
\hline & & 1 & 2 & 3 & 4 & & & & \\
\hline 1. & $\begin{array}{l}\text { Kesiapan siswa menerima } \\
\text { pelajaran }\end{array}$ & 0 & 10 & 19 & 0 & 156 & 67 & 2,31 & $42 \%$ \\
\hline 2. & memperhatikan & 3 & 16 & 10 & 0 & 156 & 65 & 2,24 & $42 \%$ \\
\hline
\end{tabular}




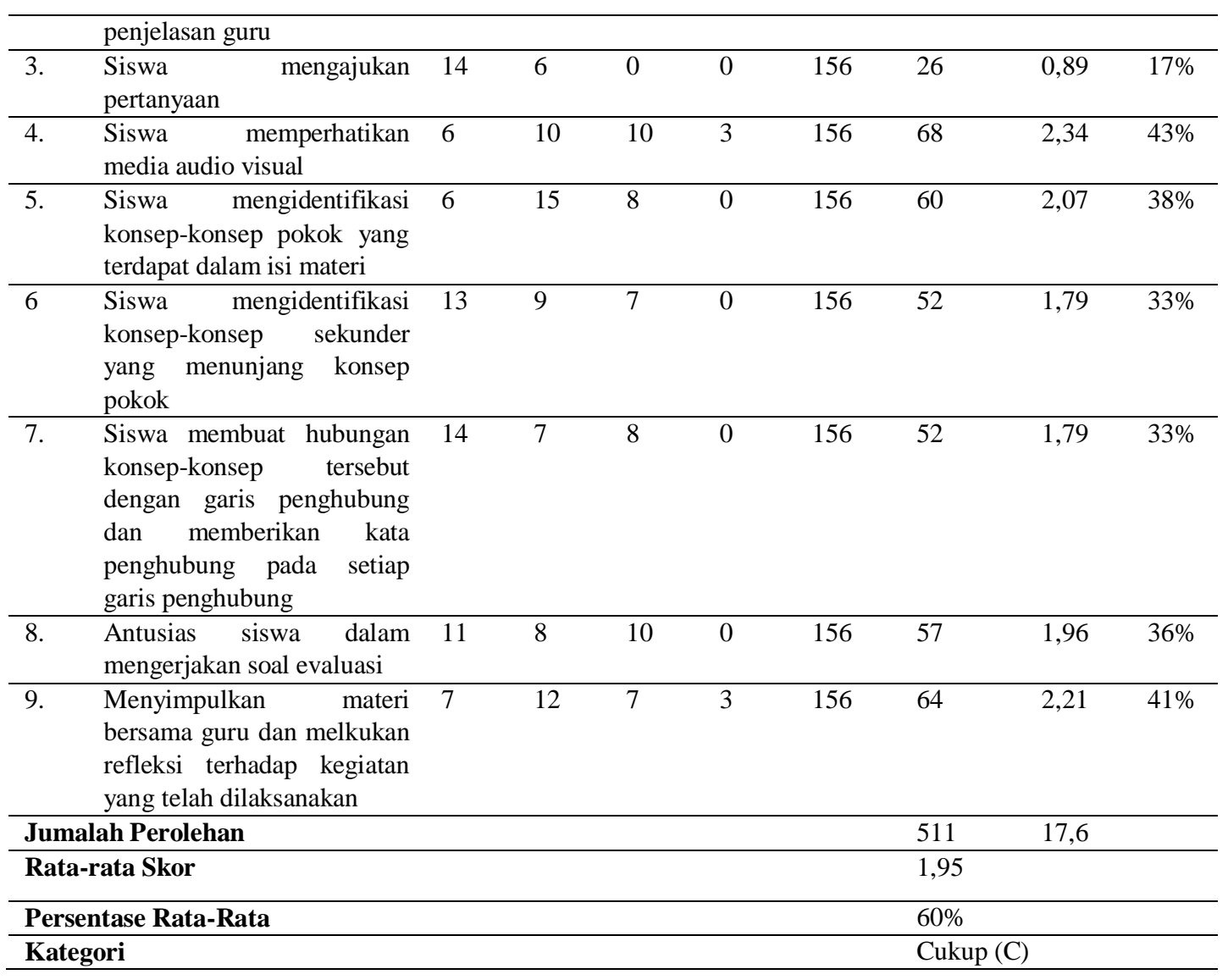

Berdasarkan data aktivitas siswa tersebut, dapat dilihat bahwa jumlah skor yang diperoleh seluruh siswa kelas V adalah 511 dengan rata-rata skor 17,6 termasuk dalam kategori cukup.

Hasil belajar siswa pada siklus I diperoleh dari kegiatan evaluasi dengan menggunakan tes pada akhir kegiatan pembelajaran IPS melalui strategi mind mapping berbasis multimedia. Siswa yang mengikuti tes berjumlah 29 siswa. Hasil evaluasi yang dilakukan oleh guru setelah proses pembelajaran menggunakan strategi mind mapping berbasis multimedia pada siklus I dibandingkan dengan data awal yang ada diperoleh data sebagai berikut:

Tabel 3. Perbandingan Hasil Belajar Data Awal dengan Siklus I

\begin{tabular}{llll}
\hline No & Pencapaian & $\begin{array}{l}\text { Data } \\
\text { Awal }\end{array}$ & $\begin{array}{l}\text { Data } \\
\text { Siklus I }\end{array}$ \\
\hline 1. & Nilai Terendah & 45 & 50 \\
\hline 2. & Nilai Tertinggi & 83 & 90 \\
\hline 3. & Rata-rata Kelas & 54,05 & 63,79 \\
\hline 4. & Ketuntasan Klasikal & $41 \%$ & $59 \%$
\end{tabular}

Data hasil belajar yang diperoleh pada data awal dengan siklus I tersebut dapat dijabarkan dalam diagram batang sebagai berikut: 


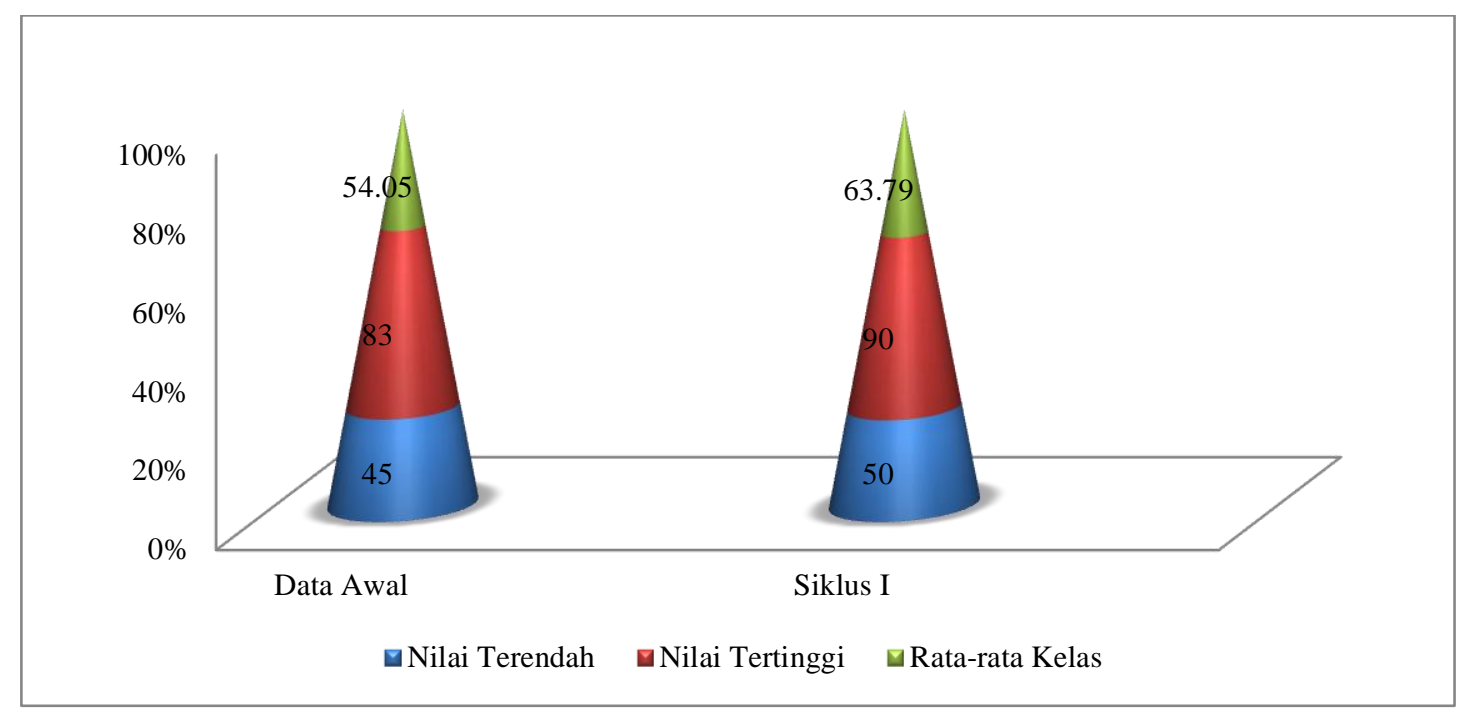

Diagram 1. Perbandingan hasil belajar data awal dengan siklus I

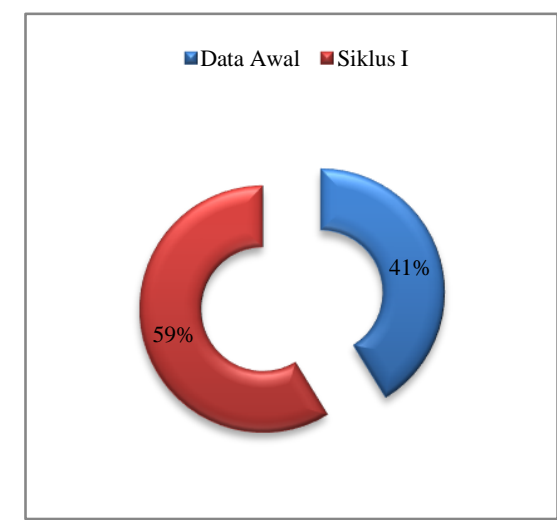

Diagram 2. perbandingan persentase ketuntasan klasikal data awal dan siklus I

Berdasarkan diagram 1 dan diagram 2 menunjukkan bahwa pada data awal sebelum dilaksanakan tindakan, nilai terendah siswa adalah 45 , nilai tertinggi 83 dengan rata-rata kelas 54,05 , dan ketuntasan klasikal $41 \%$. Setelah dilakukan tindakan melalui penerapan strategi mind mapping berbasis multimedia pada siklus I diperoleh nilai terendah 50, nilai tertinggi 90 sehingga diperoleh nilai rata-rata 63,79 dan ketuntasan klasikal 59\%.

\section{Siklus II}

Penelitian tindakan pada siklus II dilaksanakan berdasarkan hasil refleksi dari siklus I. Pelaksanaan tindakan siklus II dilaksanakan pada tanggal 17 Mei 2016.

Berdasarkan pelaksanaan tindakan yang dilakukan selama kegiatan pembelajaran IPS melalui penerapan strategi mind mapping berbasis multimedia pada siklus II, diperoleh hasil sebagai berikut.

a) Hasil observasi keterampilan guru

Kegiatan observasi dilakukan guna mengamati keterampilan guru dalam pembelajaran IPS melalui strategi mind mapping berbasis multimedia.

Tabel 4. Hasil observasi keterampilan guru siklus II

\begin{tabular}{ll}
\hline Indikator & Perolehan Skor \\
\hline 1. Keterampilan membuka pelajaran & 4 \\
\hline 2. Keterampilan memberikan pertanyaan & 3 \\
\hline 3. Keterampilan menjelaskan materi & 3 \\
\hline
\end{tabular}




\begin{tabular}{ll}
\hline 4. Keterampilan menggunakan multimedia & 4 \\
\hline 5. Keterampilan pembelajaran perseorangan & 2 \\
\hline $\begin{array}{l}\text { 6. Keterampilan membimbing diskusi kelompok } \\
\text { kecil dengan menerapkan strategi mind mapping }\end{array}$ & 3 \\
\hline 7. Keteampilan mengelola kelas & 3 \\
\hline 8. Keterampilan mengadakan variasi & 4 \\
\hline 9. Keterampilan memberikan penguatan & 3 \\
\hline 10.Keterampilan menutup pelajaran 2 & 3 \\
\hline Total Skor & 32 \\
\hline Persentase & $80 \%$ \\
\hline Kategori & Baik \\
\hline
\end{tabular}

b) Hasil observasi aktivitas siswa

Hasil observasi siswa pada pelaksanaan tindakan siklus II pada pembelajaran IPS melalui penerapan strategi mind mapping berbasis multimedia di kelas V SDN Wonorejo I, dapat dilihat pada tabel berikut:

Tabel 5. Hasil Observasi Aktivitas Siswa Siklus II

\begin{tabular}{|c|c|c|c|c|c|c|c|c|c|}
\hline \multirow[t]{2}{*}{ No. } & \multirow[t]{2}{*}{ Aspek yang dinilai } & \multicolumn{4}{|c|}{$\begin{array}{l}\text { Jumlah siswa yang } \\
\text { mendapatkan skor }\end{array}$} & \multirow[t]{2}{*}{$\begin{array}{l}\text { Skor } \\
\text { Mak. }\end{array}$} & \multirow{2}{*}{$\begin{array}{l}\text { Jumlah } \\
\text { Skor }\end{array}$} & \multirow{2}{*}{$\begin{array}{l}\text { Rata- } \\
\text { rata }\end{array}$} & \multirow[t]{2}{*}{$\%$} \\
\hline & & 1 & 2 & 3 & 4 & & & & \\
\hline 1. & $\begin{array}{l}\text { Kesiapan siswa } \\
\text { menerima pelajaran }\end{array}$ & 0 & 0 & 14 & 15 & 156 & 102 & 3,5 & $65 \%$ \\
\hline 2. & $\begin{array}{l}\text { Siswa memperhatikan } \\
\text { penjelasan guru }\end{array}$ & 0 & 8 & 8 & 13 & 156 & 92 & 3,2 & $60 \%$ \\
\hline 3. & $\begin{array}{l}\text { Siswa mengajukan } \\
\text { pertanyaan }\end{array}$ & 0 & 10 & 14 & 5 & 156 & 82 & 2,8 & $53 \%$ \\
\hline 4. & $\begin{array}{l}\text { Siswa memperhatikan } \\
\text { media audio visual }\end{array}$ & 0 & 5 & 10 & 14 & 156 & 96 & 3,3 & $62 \%$ \\
\hline 5. & $\begin{array}{l}\text { Siswa mengidentifikasi } \\
\text { konsep-konsep pokok } \\
\text { yang terdapat dalam isi } \\
\text { materi }\end{array}$ & 0 & 9 & 10 & 10 & 156 & 88 & 3,0 & $56 \%$ \\
\hline 6 & $\begin{array}{l}\text { Siswa mengidentifikasi } \\
\text { konsep-konsep sekunder } \\
\text { yang menunjang konsep } \\
\text { pokok }\end{array}$ & 0 & 10 & 14 & 5 & 156 & 82 & 2,8 & $53 \%$ \\
\hline 7. & $\begin{array}{l}\text { Siswa membuat } \\
\text { hubungan konsep- } \\
\text { konsep tersebut dengan } \\
\text { garis penghubung dan } \\
\text { memberikan kata } \\
\text { penghubung pada setiap } \\
\text { garis penghubung }\end{array}$ & 0 & 5 & 15 & 9 & 156 & 91 & 3,1 & $58 \%$ \\
\hline 8. & $\begin{array}{lr}\text { Antusias siswa } & \text { dalam } \\
\text { mengerjakan } & \text { soal } \\
\text { evaluasi } & \\
\end{array}$ & 0 & 11 & 10 & 8 & 156 & 84 & 2,9 & $54 \%$ \\
\hline 9. & $\begin{array}{l}\text { Menyimpulkan materi } \\
\text { bersama guru dan } \\
\text { melkukan refleksi } \\
\text { terhadap kegiatan yang } \\
\text { telah dilaksanakan }\end{array}$ & 0 & 4 & 5 & 20 & 156 & 103 & 3,6 & $66 \%$ \\
\hline Jum & ah Perolehan & & & & & & 820 & 28,21 & \\
\hline Rata & rata Skor & & & & & & 3,13 & & \\
\hline Pers & itase Rata-Rata & & & & & & $97 \%$ & & \\
\hline Kate & & & & & & & Sangat B & & \\
\hline
\end{tabular}


Berdasarkan data aktivitas siswa tersebut, dapat dilihat bahwa jumlah skor yang diperoleh seluruh siswa kelas $\mathrm{V}$ adalah 820 dengan ratarata skor 28,21 termasuk dalam kategori sangat baik.
Hasil evaluasi yang dilakukan oleh guru setelah proses pembelajaran menggunakan strategi mind mapping berbasis multimedia pada siklus II dibandingkan dengan siklus I diperoleh data sebagai berikut.

Tabel 6. Perbandingan Hasil Belajar Siklus dengan Siklus II

\begin{tabular}{llll}
\hline No & Pencapaian & $\begin{array}{l}\text { Data } \\
\text { Siklus I }\end{array}$ & $\begin{array}{l}\text { Data } \\
\text { Siklus II }\end{array}$ \\
\hline 1. & Nilai Terendah & 50 & 65 \\
\hline 2. & Nilai Tertinggi & 90 & 95 \\
\hline 3. & Rata-rata Kelas & 63,79 & 85,35 \\
\hline 4. & Ketuntasan Klasikal & $59 \%$ & 86,25 \\
\hline
\end{tabular}

Berdasarkan tabel 6 tersebut, dapat diketahuai adanya peningkatan hasil belajar yang diperoleh pada pelaksanaan siklus I dan siklus II. Nilai terendah pada siklus II yakni 65 , nilai tertinggi 95 , rata-rata kelas 85,35 serta ketuntasan klasikal 86,25.

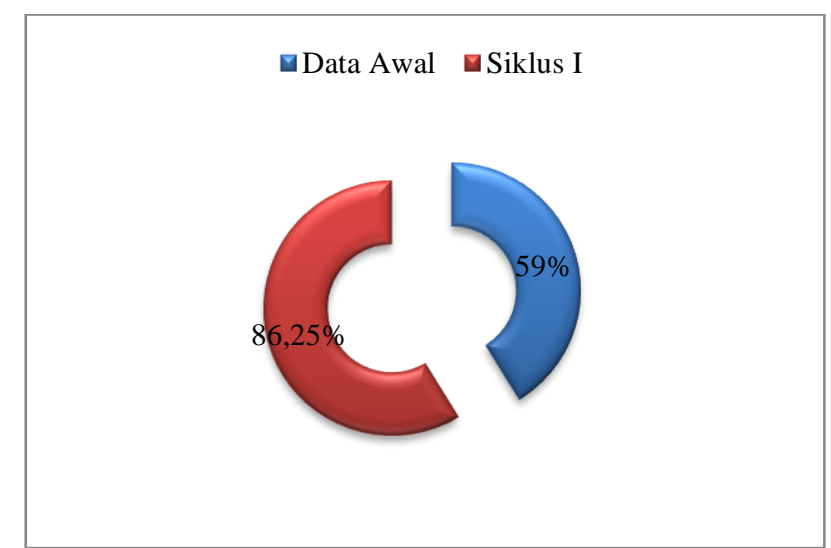

\section{Diagram 3. perbandingan persentase ketuntasan klasikal siklus I dan siklus II}

Hasil belajar siswa mengalami peningktan pada setiap siklusnya dapat dilihat pada gambar berikut:

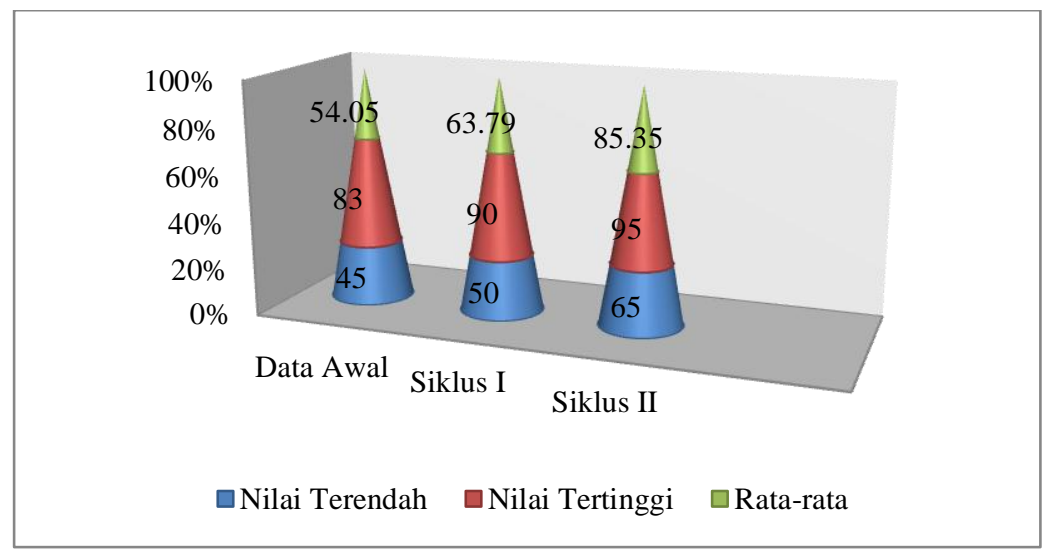

Diagram 4. Perbandingan Hasil Belajar Siswa Setiap Siklus.

Berdasarkan pemaparan data tersebut maka dapat disimpulkan bahwa penerapan strategi belajar mind mapping berbasis multimedia dalam meningkatkan kualitas pembelajaran IPS pada siswa kelas V SDN I Wonorejo berhasil, kualitas pembelajaran yang dikaji meliputi tiga 
aspek yaitu keterampilan guru, aktivitas siswa, dan hasil belajar telah mencapai bahkan melebihi indikator penelitian yang telah ditetapkan sehingga penelitian ini tidak dilanjutkan pada siklus berikutnya.

\section{SIMPULAN}

Berdasarkan hasil penelitian tindakan kelas pada pembelajaran IPS melalui penerapan strategi mind mapping berbasis multimedia pada siswa kels V SDN I Wonorejo dapat disimpulkan bahwa strategi pembelajaran tersebut dapat membantu meningkatkan hasil belajar siswa. Strategi mind mapping berbasis multimedia dapat meningkatkan keterampilan guru, hal ini ditunjukkan dengan peningkatan keterampilan guru pada setiap siklusnya. Pada siklus I keterampilan guru mendapatkan skor 24 dengan kategori cukup dan siklus II mendapatkan skor 32 dengan kategori baik. Aktivitas siswa dalam pembelajaran IPS melalui penerapan strategi mind mapping berbasis multimedia dapat meningkat. Pada siklus I aktivitas siswa memperoleh jumlah rerata 17,6, dengan persentase rata-rata $60 \%$, dalam kategori cukup. Setelah dilakukan perbaikan pada siklus II aktivitas siswa meningkat menjadi 28,21 atau sebesar $97 \%$ dalam kategori sangat baik. Aktivitas siswa dalam pembelajaran IPS melalui strategi mind mapping berbasis multimedia dinilai telah mencapai indikator keberhasilan.

Ketuntasan klasikal hasil belajar siswa melalui penerapan strategi peta konsep dengan media audio visual mengalami peningkatan. Dari siklus I, persentase ketuntasan klasikal $59 \%$ dengan kategori cukup dan siklus II ketuntasan hasil belajar siswa sebesar 86,25\% dengan kategori sangat baik. Hasil belajar IPS siswa kelas V SDN I Wonorejo mengalami ketuntasan klasikal minimal sebesar $75 \%$.

\section{DAFTAR PUSTAKA}

Arikunto, Suharsimi. 2009. Penelitian Tindakan Kelas. Jakarta : Bumi Aksara.

Astutiamin. (2009). Meningkatkan Hasil Belajar dan Kreativitas Siswa melalui Pembelajaran Berbasis Peta Pikiran (Mind Mapping). $\underline{\mathrm{http}: / / \text { astutiamin.wordpress.com }}$ /2009/11/26/meningkatkanhasilbelajar-dan-kreativitas$\underline{\text { siswa-melalui-pembelajaran- }}$ berbasis-petapikiran-mindmapping/\#more-30 (diakses 10 Februari 2016).

Buzan. 2007. Buku Pintar Mind Map. Jakarta: Gramedia Pustaka Utama.

Depdiknas. 2006. Lampiran Permendiknas Nomor 22 tahun 2006 tentang Standar Isi. Jakarta: Depdiknas.

Depdiknas. 2007. Naskah Akademik Kajian Kebijakan Kurikulum Mata Pelajaran Ilmu Pengetahuan Sosial (IPS). Jakarta: Departemen Pendidikan Nasional Badan Penelitian dan Pengembangan Pusat Kurikulum.

Poerwanti, Endang. 2008. Asesmen Pembelajaran SD. Jakarta: Dirjen Dikti. Depdiknas. 